\title{
What Holds Women Back in Academic Leadership Positions: A Case Study in The Gulf Cooperation Council (GCC)
}

\author{
Maram Salah Jaradat \\ Department of Professional Diploma in Teaching \\ College of Education, Humanities and Social Sciences \\ Al Ain University of Science and Technology (AAU)
}

\begin{abstract}
The purpose of this study was to discover the challenges preventing women from advancing in academic leadership positions. It also investigated the scope of support and acceptance of women as leaders in their workplace including administration. The study was conducted in a private university in the United Arab Emirates using a quantitative online survey. The data were collected from 115 academic women including (68) working in administrative positions and (47) in non-administrative positions.. The results showed that the most significant challenges women in leadership positions face are lack of colleagues' support $\left(.515^{* *}\right)$, men not accepting women as leaders $\left(.467^{* *}\right)$, society not accepting women as leaders $\left(.389^{* *}\right)$ and lack of confidence in women $\left(.389^{* *}\right)$.
\end{abstract}

Keywords: academic women, administration, challenges, factors, women’s leadership

\section{INTRODUCTION}

There are lots of women who serve as models of leadership and have become inspiring leaders for other women to follow. However, while the world is evolving, women in general are still lagging behind when it comes to leadership roles. With women still pushing to reach the top, they face various challenges that many of their male counterparts do not have an understanding of, and which are preventing many women from achieving their goals of becoming leaders at their workplaces and diminishing their ability to get ahead .

In academia, leading women are no exception, indeed the examples are abundant of women who achieved the highest academic ranks and accomplishments same as their male colleagues. Yet for all their academic achievements, these women represent a small percent of leaders overall. It is no wonder that they have even been ignored from holding administrative positions to the account of their male colleagues. Thus, it is important to understand the environment and the barriers that hold women back in leadership positions and the challenges they face.

In the Arab world, there is not much support for women leadership as much as there is for men. Women indeed face additional barriers to success in the form of societal expectations of women and customs. The reasons may vary from society to women themselves not believing in other women's abilities to succeed as leaders, or being raised in hesitancy to lain into leading in an Arab society. Having more women in leadership positions in the Arab world will bring various perspectives in the workforce and create new ideas that might serve all institutions in the society. Thus, it is important to have a diverse society of women and men to have that harmony in life, with this diversity effectively implemented and activated in leadership issues too. 
The importance of this study evolves from this point where the United Arab Emirates (UAE) is a diverse society of different men and women representing diverse nationalities, and where women have recently been appointed in leadership positions and thus they are seeking to prove that women enjoy the same skills and capabilities as men sharing in the growth of the society.

\section{Purpose of Study}

The purpose of this study is to discover the challenges women face in leadership positions that prevent them from taking steps toward leadership positions.

\section{LITERATURE REVIEW}

A simple definition of leadership is "the art of motivating a group of people to act towards achieving a common goal" (Ward, 2018). This definition according to Ward captures the essentials of being able and willing to inspire others. Yukl (1994) define leadership as the process of giving purpose to collective effort, and expending willing effort to achieve purpose. So effective leadership is based upon ideas that can be communicated to others in a way that engages them enough to act, as the leader wants them to act. From the above definitions, it is deduced that leadership is closely linked to performance and thus any leadership definition has to consider it.

A leader is a person who possesses the combination of personality and leadership skills that makes others follow him or her. In other words, the leader is the inspiration and director of the action (Ward, 2018). Not necessarily related to profit, but those who are viewed as effective leaders, are the ones who increase their company's bottom lines and accomplishments. To be an effective leader, certainly he/she has to manage the resources at one's disposal. Nevertheless, must also possess primary leadership skills such as communicating, inspiring and supervising - just to name a few (Ward, 2018).

\section{Women's Leadership}

Female leadership is necessary in teams, organizations and in society. That is why we need leaders from both genders to complement each other. Organizations nowadays have strong internal policies in support of gender diversity, indeed some prefer women for certain positions as they have experienced the benefits of female leadership.

According to researchers, when women assume a leadership role they experiment changes in their behavior: some of their unique features are intensified; features that had previously not been part of their character appear stronger; they have a faster discerning capacity and precision in making decisions (ConnectAmericas, 2015).

According to Misquitta (2016), feminine leadership style is known to be socially inclined in which crucial and personal attention is given to subordinates and to maintaining a good working environment, meanwhile the masculine leadership style is known to be instrumental and instruction giving. Appelbaum et al. (2013) argue that the most effective leadership style is transformational leadership, which is associated with characteristics considered more typical of women. This style suggests that leaders and followers help each other to advance to a higher level, and that leaders act as role models motivating others to go beyond the confines of their jobs, and support developing the subordinates' skills in addition to fostering good relationships. 


\section{The Challenges Women Face in Leadership}

Organizations today place multiple demands on those holding leading positions, requiring them to impart vision, initiate change, and make difficult decisions (Mwangi, 2012). In the quest to undertake their mandate, the leaders face a number of challenges both internally and externally (Johnson \& Scholes, 2003). The internal challenges arise from the job and the organizational environment whereas the external challenges are from outside the organization such as personal and family.

A report by Desvaux, Devillard-Hoellinger, and Baumgarten (2007) states that, in order to increase the proportion of female leaders, the modern model of male-oriented leadership style need to be changed, which requires unfailing availability and total geographical mobility. The report also states that companies must be innovative and willing to create flexible work environments.

In terms of academia, women also have much in common with their counterparts in other workforces, and the reasons for the lack of female leadership do not fall exactly in system or self, but into both categories. In this article, the researcher intend to examine a number of challenges women face in leadership roles based on the reviewed literature. These challenges include society not accepting women as their leaders, lack of support, career priorities, worklife balance, and workload.

\section{Society not Accepting Women as Leaders}

The societal assumptions about an ideal leader in an organization can have different impact on men and women. According to Williams (2000), the predominant view of this leader is someone who enters a career immediately upon attaining the appropriate degree, and then works his/her way up the corporate ladder with no career interruptions, making substantial time commitments to the organization and making primarily a financial contribution to family life. In reality, many women take breaks in their careers, work reduced hours, or otherwise contribute large amounts of time to caring for children and responding to family needs. Such breaks can prevent women from being seen as ideal leaders and candidates for top positions; thus, usually men are the ones who take over leading positions (April, Dreyer \& Blass, 2007).

In his study, Adkins (2006) found that executive women in the US and the UK felt that the greatest deep-rooted barrier to leadership comes from the society itself, because of the perception that women are not patterned for top leading managerial positions. April et al. (2007) also argues that while women in South Africa have more opportunities, and therefore potentially more economic power available to them than their male counterparts, there is also a societal perception that women have been appointed to executive positions as part of affirmative action initiatives rather than because they have the requisite skills, experience, and qualifications.

\section{Lack of Colleagues' Support}

Mentoring schemes can be particularly important for women. The Catalyst study of MBA graduates found that $61 \%$ of women found a lack of a mentor as a barrier to career development, compared with $31 \%$ of men (Carter \& Silva, 2010). A formal mentoring scheme could provide invaluable support, particularly with proper training for the mentor and careful matching of mentor and mentee.

Same as supporting individuals, mentoring schemes can benefit the organization as a whole. Based on a German study, it is quite helpful mentoring women by men, where the benefit is for not only women but also men, as they learn about specific problems and barriers that women 
experience through personal direct interaction. Furthermore, the organization makes better use of its female employees and thus increases productivity (Manz \& Rosmann, 2002).

\section{Career Priorities}

Men and women are more similar than different, yet the differences exist in biological, neurological, and psychological dimensions (Hopkins et al, 2008). Such as their techniques of information processing, prioritizing tasks, responding to stress, as well as their methods of motivation (Ruderman \& Ohlott, 2005). Men and women also have divergent conceptions of career success. One study found that women tend to define career success as an interest in intrinsically rewarding roles, personal achievements, self-development, and work-life balance, whereas men tend to view success as high salaries, moving up the corporate ladder, and achieving status (Sturges, 1999). Women also face a distinct set of career decision factors. In this regard, Mainiero and Sullivan (2005) propose that women take into account multiple life roles, which creates varying importance of emphasis on challenge, balance, and authenticity for women during their early, middle, and later stages of careers.

\section{Work-Life Balance}

Women experience competing priorities for their time and attention across life and career stages that are different for men (Mainiero \& Sullivan, 2006). Whereas men are framed as the bread-earners, women are framed as the homemakers and mothers. At the time men try to swap family responsibilities against work responsibilities, women try to balance their work and family roles, tending to assign greater priorities and more time to their family responsibilities, independent of their work demands (Aryee et al., 2005). A study by European commission (2000) found that women's employment starts to decrease when they have young children, whereas men between 20-44 years old are more likely to be in employment when there is a child in the household.

Mwangi (2012) argue that unlike male managers, the female managers face the challenges of resolving the inevitable conflicts between the traditional female and family roles and the role of managerial/administrative leadership. Leden et al. (2007), posit that an aspect of these role conflicts is the problem of balancing time between the traditional familial role and the managerial/administrative role. Both male and female leaders are subject to this conflict, but since women are the ones who bear the heaviest load of family work in most cultures, men face fewer and different role conflicts than women

Usually women resolve these conflicts in several settings such as (i) preserving the degrees of career and geographic mobility, (ii) sorting priorities at different points in time that the path to top leadership may require, (iii) dealing with the consequences of career interruptions that are more common among females early in their careers than among males, and (iv) managing childbirth and child-rearing, which are traditional female roles (Rothbard, 2001).

\section{Workload}

According to a CIA report (2013), women in the American workplace face many challenges, including lack of sponsors, bias and harassment, insufficient workplace flexibility, an increasing volume of workload, and personal responsibilities, which may lead to voluntarily taking time off from a career at a higher rate than their male counterparts.

In a different context, Paavo (2006) interviewed number of women in Canadian union leadership to examine the effect of workload on women working in leadership positions. Their experiences confirm what others have previously identified as the nature and effects of workload on women everywhere. The lack of official recognition of the problem, to say nothing 
of the lack of concrete strategies to address overwork, continued the exclusion of women and other workers from union-movement leadership.

Lundberg and Frankenhaeuser (1999) investigated the effects of stress and workload of both men and women in high-ranking positions. They found that women were more stressed by their greater unpaid workload and by a greater responsibility for duties related to home and family. Women had higher norepinephrine levels than men did, both during and after work, which reflected their greater workload they suffer from.

\section{METHODOLOGY}

This study used a quantitative design to examine the relationships between women's perceptions and the factors facing them in leadership positions. Data was collected by a crosssectional web-based survey using a questionnaire. The benefits of the web-based survey are overcoming time and space boundaries, ease of data entry (Batinic, Reips \& Bosnjak, 2002), and cost-effectiveness by distributing online (Weathington, Cunningham \& Pittenger, 2010).

\section{Sample and Sampling Technique}

The sample consisted of 115 academic women at Al Ain University of Science and Technology in the UAE. The sampling technique used was simple random sampling, which includes samples of whoever available at the time of conducting the study (Gay \& Airasian, 2003).

\section{Instrument}

The instrument used to collect data was a questionnaire that consisted of items inspecting the challenges women face in leadership. This questionnaire was adopted from Al-Jaradat's research (2014) and was modified to match the current study. All the items in the original questionnaire were designed based on Likert's five-point scale. For the validity, Al-Jaradat (2014) reported that the items in his questionnaire were presented to a number of specialized arbitrators $(n=30)$ in education and educational leadership and applied the questionnaire on an exploratory sample $(n=20)$ of women leaders. He worked on the correlation coefficient between items and their domains, all of which were at $(\leq 0.05)$ significance level. As for the reliability, by employing Chronobach Alpha coefficient, his results showed that the reliability coefficient was (0.95), indicating the questionnaire was fit for the his study.

After receiving the approval from Al-Jaradat to use his questionnaire, the researcher of the current study made the necessary modifications on the questionnaire and used it in her study. Based on her thorough reading, the researcher developed the rest of the items in her instrument. All the added items were designed based on the same Likert's five-point scale. For the validity and reliability of these items, the researcher shared them with professional specialized educators in education and educational leadership $(n=7)$. They were asked to examine the relatedness of the items based on the domains they measure and she applied their comments. Before sharing it with the targeted participants, the researcher also applied the instrument to a sample that consisted of (10) members of the study population and took their remarks and comments into consideration.

\section{Data Collection and Analysis}

Data were collected through an online survey that was shared with a large number of women throughout University Moodle, Emails and Whatsapp. The researcher designed the online survey using Google Drive Docs before sharing the link through these networking sites. 
Data were analysed using the Statistical Package for Social Sciences (SPSS), allowing the researcher to do the relevant statistical analysis. Using the proper tests to analyze the data, the researcher came up with the following results.

\section{Demographics}

\section{RESULTS}

A total of 115 women participated in this study as seen in Table 1 below. 68 of them have administrative leadership positions, while 47 are academics who have non-administrative leadership positions. Their ages ranged between 28 and 56. Out of the 68 women in administrative positions; 27 hold Bachelor degrees, 23 hold Master degrees and 18 hold Doctoral degrees. Meanwhile, out of the 47 women not in administrative positions; 44 hold Bachelor degrees, 1 holds Master degree and 2 hold Doctoral degrees.

Table 1

Participants' Demographics ( $=115)$

\begin{tabular}{ccccccc}
\hline $\begin{array}{l}\text { Administrative } \\
\text { Position }\end{array}$ & \multirow{2}{*}{ No. } & \multicolumn{2}{c}{ Marital Status } & \multicolumn{3}{c}{ Level of Education } \\
\cline { 3 - 7 } & & Single & Married & B & M & D \\
\hline Yes & 68 & 39 & 29 & 27 & 23 & 18 \\
No & 47 & 2 & 45 & 44 & 1 & 2 \\
\hline
\end{tabular}

\section{Challenges Facing Women}

Looking at the challenges women face in leadership, the study found that women in administrative and non-administrative leadership positions face a number of challenges as seen in Table 2 . The results show that (50\%) of all participating women find that 'balance work and home responsibilities' is the highest challenge. As for statement 'Men do not accept women as their leaders', it was the second challenge reported by participating women (35\%), followed by 'career priorities' (25\%), then 'society not accepting women as leaders' (21\%).

Table 2

Challenges facing women in leadership ( $\mathrm{N}=115)$

\begin{tabular}{llc}
\hline The Challenge & No. & Percentage \\
\hline Balance work and home & $(34)$ & $50 \%$ \\
Men do not accept women as their leaders & $(24)$ & $35 \%$ \\
Career priorities & $(17)$ & $25 \%$ \\
Society not accepting women as leaders & $(14)$ & $21 \%$ \\
Completing workload & $(13)$ & $19 \%$ \\
Lack of colleagues' support & $(12)$ & $12 \%$ \\
\hline
\end{tabular}

Table 3 below displays the results of the mean scores and standard deviations of the challenges women in administrative positions face. The values of the mean and standard deviation for 'balance work and home' variable show that it is the highest influencing variable women face in administrative positions, followed by 'men do not accept women as their leaders'. The third influencing variable was 'completing workload'. As noticed, the means and standard deviations for 'Career priorities' and 'Society not accepting women as leaders' are very similar.

Table 3

Means and Standard Deviations of challenges facing women in administrative positions ( $=68$ )

\begin{tabular}{llll}
\hline & The Challenge & M & St.d \\
\hline Women in admin. positions & Balance work and home & 3.59 & 1.2 \\
Women in admin. positions & Men do not accept women as their leaders & 3.29 & 1.3 \\
Women in admin. positions & Career priorities & 2.88 & 1.3 \\
Women in admin. positions & Society not accepting women as leaders & 2.87 & 1.3 \\
Women in admin. positions & Completing workload & 3.08 & 1.2 \\
Women in admin. positions & Lack of colleagues' support & 2.66 & 1.2 \\
\hline
\end{tabular}


In order to examine the challenges women face in their administrative positions, a correlational analysis was used. To meet that end, Person $r$ correlations were used in this study as they enabled the researcher to describe the relationships between the variables used in the survey. Table 4 presents the correlational analysis of the challenges. As seen, there is a significant correlation between women in administrative positions and 'lack of colleagues' support' ( $p=.515^{* *}$ ), followed by 'men do not accept women as their leaders' ( $p=.467^{* *}$ ). Following were both 'lack of confidence in women's abilities' and 'society not accepting women as leaders' ( $\left.p=.389^{* *}\right)$. As for 'completing workload' $\left(p=.341^{* *}\right)$ and 'balance between work and home' $\left(p=.285^{* *}\right)$, they came last.

Table 4

Correlations values of challenges facing women in administrative positions $(\mathrm{N}=68)$

\begin{tabular}{llcc}
\hline & \multicolumn{1}{c}{ Challenge } & $\begin{array}{c}\text { Pearson } \\
\text { Correlation }\end{array}$ & $\begin{array}{c}\text { Sig. (2- } \\
\text { tailed) }\end{array}$ \\
\hline Women in admin. positions & Balance work and home & $.285^{* *}$ & .002 \\
Women in admin. positions & Completing workload & $.341^{* *}$ & .000 \\
Women in admin. positions & Lack of colleagues' support & $.515^{* *}$ & .000 \\
Women in admin. positions & Lack of confidence in women's abilities & $.389^{* *}$ & .000 \\
Women in admin. positions & Men do not accept women as their leaders & $.467^{* *}$ & .000 \\
Women in admin. positions & Society not accepting women as leaders & $.389^{* *}$ & .000 \\
\hline
\end{tabular}

** Correlation is significant at the 0.01 level (2-tailed)

\section{DISCUSSION}

The study focused on discovering the challenges women face in leadership positions. The results showed that $50 \%$ of women in administrative and non-administrative leadership positions found that 'balance work and home responsibilities' is the highest challenge, followed $35 \%$ of them saying that 'Men do not accept women as their leaders' is the second challenge. This result shows that women are influenced by society discrimination between men and women and other responsibilities.

Based on the results regarding the issue of challenges facing women in administrative positions, the study found that 'lack of colleagues' support' followed by 'men not accepting women as their leaders' are the most challenges women in administrative positions face. The next challenges were 'society not accepting women as leaders' and 'lack of confidence in women's abilities'. This is in agreement with the male-oriented model of leadership style that is really a big challenge that facing any trial to change this perspective to a new modern model that does not lain into the gender issue.

In general the results indicate that more attention need to be paid to the abilities, skills, and potentials of women in order to bring real competitive advantage to institutions to have more successful women in men's world.

\section{CONCLUSION}

In conclusion, there are three main points that need to take into consideration when discussing women in leadership positions. First, there is a need for institutional strategies to develop women leaders in different sections. Second, there is a need for implementing new visions of change and acceptance to what is good for achieving organizational objectives. Finally, it is important for both women and organizations as a whole to consider these challenges that prevent women to be on top, and to work together to eliminate them and create a genderbalanced working environment that support both men and women to be on top positions. 


\section{References}

Adkins, K. (2006). Glass ceiling not cracked for executives. American Society for Training \& Develo `pment, 60(6), 16

Al-Jaradat, M. K. M (2014). Challenges facing women academic leadership in secondary schools of Irbid educational area. International Educational Studies Journal, 7(5), 147-160.

Appelbaum, S., Shapiro, B., Didus, K., Luongo, T. \& Paz, B. (2013). Upward mobility for women managers: Styles and perceptions: Part two. Industrial and Commercial Training, 45(2), 110-118. doi:10.1108/00197851311309552

April, K., Dreyer, S., \& Blass, E. (2007). Gender impediments to the South African executive boardroom. South African Journal of Labour Relations, 31(2), 51-67.

Aryee, S., Srinivas, E.S., \& Tan, H.H. (2005). Rhythms of life: Antecedents and outcomes of work-family balance in employed parents. Journal of Applied Psychology, 90(1), 132-46.

Batinic, B., Reips, U., \& Bosnjak, M. (2002). Online social sciences. Seatle, USA: Hogrefe \& Hubber Publisher.

Carter, N. M., \& Silva, C. (2010). Pipeline's broken promise - The promise of future leadership: A research program on highly talented employees in the pipeline. Retrieved July 27, 2018 from

https://www.catalyst.org/system/files/Pipeline\%27s_Broken_Promise_Final_021710.pdf

CIA report (2013). Director's advisory group on women in leadership: Unclassified report. Retrieved July 25, 2018 from https://www.cia.gov/library/reports/CIA Women_In_Leadership_March2013.pdf

Desvaux, G., Devillard-Hoellinger, S., \& Baumgarten, P. (2007). Women matter: Gender diversity, a corporate performance driver. France: McKinsey \& Company. Retrieved July 29, 2018 from https://www.raeng.org.uk/publications/other/women-matter-oct-2007

Gay, L., \& Airasian, P. (2003). Educational research: Competencies for analysis and applications. NJ: Pearson Education.

Hopkins, M. M, O’Neil, D. A., Passarelli, A., \& Bilimoria, D. (2008). Women's leadership development strategic practices for women and organizations. Consulting Psychology Journal: Practice and Research, 60(4), 348-365. Retrieved July 26, 2018 from

https://www.researchgate.net/publication/232509932_Women's_leadership_development_strategic_practices_fo r_women_and_organizations

Johnson, G., \& Scholes, K. (2003). Exploring corporate strategy (6 $6^{\text {th }}$ ed.). Englewood Cliffs: NJ: Prentice Hall.

Leden, A., Bornmann, L., Gannon, \& F., Wallon, G. (2007). A persistent problem: Traditional gender roles hold back female scientists. EMBO Reports, 8(11), 982-7.

Lundberg, U., \& Frankenhaeuser, M. (1999). Stress and workload of men and women in high-ranking positions. Journal of Occupational Health Psychology, 4(2),142-51. Retrieved November 22, 2018 from https://www.researchgate.net/publication/13085223_Stress_and_workload_of_men_and_women_in_highranking_positions

Mainiero, L. A., \& Sullivan, S. E. (2005). Kaleidoscope careers: An alternate explanation for the "opt-out" revolution. Academy of Management Executive, 19, 106-123.

Mainiero, L. A., \& Sullivan, S. E. (2006). The opt-out revolt: Why people are leaving companies to create kaleidoscope careers. Mountain View, CA: Davies-Black Publishing.

Manz, H., and Rossman, G. (2002). Promoting women. EMBO Reports, 3(1), 5-8.

Misquitta, F. M. (2016). Women in leadership: Comparing issues in a developed versus a developing economy. Master Thesis, Auckland University.

Mwangi, M. (2012). Challenges facing women in managerial positions at the Standard Group Limited. Master Thesis, University of Nairobi. Retrieved July 27, 2018 from http://erepository.uonbi.ac.ke/bitstream/handle/11295/12697/Njoki_Challenges\%20Facing\%20Women\%20in \%20Managerial\%20Positions\%20at\%20the\%20Standard\%20Group\%20Limited.pdf?sequence=6

Paavo, A. (2006, Spring). Union workload: A barrier to women surviving labour-movement leadership. Just Labour, 8, 1-9. Retrieved November 22, 2018 from http://www.justlabour.yorku.ca/volume8/pdfs/01\%20Paavo\%20Press.pdf

Rothbard, N. P. (2001). Enriching or depleting? The dynamics of engagement in work and family roles. Administrative Science Quarterly, 46(4), 655-84. 
Ruderman, M. N., \& Ohlott, P. J. (2005). Leading roles: What coaches of women need to know. Leadership in Action, 25, 3-9.

Sturges, J. (1999). What it means to succeed: Personal conceptions of career success held by male and female managers at different ages. British Journal of Management, 10, 239-252.

Ward, S. (2018). Leadership definition: What is leadership? and can you learn to be a good leader? Retrieved July 25, 2018 from https://www.thebalancesmb.com/leadership-definition-2948275

Weathington, B. L., Cunningham, C. J., \& Pittenger, D. J. (2010). Research methods for the behavioral and social sciences. Hoboken, NJ: John Wiley \& Sons, Inc.

Williams, J. (2000). Unbending gender: Why work and family conflict and what to do about it. New York: Oxford University Press.

Yukl, G. (1994). Leadership in organizations (3 $3^{\text {rd }}$ ed.). Englewood Cliffs: NJ: Prentice-Hall. 